\title{
Film Tourism in South-Eastern Sicily: In the Footsteps of Inspector Montalbano
}

\author{
By Vincenzo Asero* \& Douglas Mark Ponton ${ }^{ \pm}$
}

\begin{abstract}
This study focuses on film tourism on the island of Sicily, in the context of the popular television series, Montalbano. Since the series began, there have been increases in tourist flows in the towns most directly interested. Although it is impossible to say that the Montalbano series is directly responsible for these phenomena, it has succeeded in bringing visibility to the territories and landscapes of the area. In the tourist sector, there are now abundant possibilities for fans to participate in movie tours. The apparent success of the series and its tourist spin-offs can be problematised, therefore, since it raises questions about authenticity from the perspective of the subjectivity of the tourists. Authenticity, for a tourist on a 'Montalbano tour', relates more to the desire to explore a virtual reality than to the traditional attractions of the places. The issue of authenticity has contrasting implications for the areas involved. The location of 'Vigata', a fictional creation of author Andrea Camilleri, has become an issue, as towns compete for a share of the rapidly evolving tourist market, engaging in attempts to demonstrate authentic traces of the fictional context. The paper explores these issues from an interdisciplinary, mixed methods perspective that combines insights from the fields of Economics and Linguistics. Data are analysed in terms of the multimodal and discourse-pragmatic dimensions of the interpretation of image-texts.
\end{abstract}

Keywords: Montalbano, film tourism, framing, multimodality, destination branding

\section{Introduction}

Film tourism is recognised as a driver of tourism development for many destinations (Connell 2012). As Bruner (2005) says, it combines the mobility of populations with the effects of mass media, and thus represents a quintessentially post-modern phenomenon (see also Macionis 2004). There are evident reasons why successful films should produce spin-off effects in the area of tourism, as devotees wish to visit the places where they were set (Busby and Klug 2001). These processes have only accelerated in recent years with the establishment of social media platforms such as Facebook and Instagram, and the increasing availability of budget airlines and accommodation solutions.

Butler (1999) underlines the power of mass entertainment, including films and videos, in the development of tourism destinations, which influence travel choices by creating a priori images of what a destination and its people may look

\footnotetext{
*Assistant Professor in Economics, Department of Political and Social Sciences, University of Catania, Italy.

${ }^{ \pm}$Associate Professor of English Language and Translation, Department of Political and Social Sciences, University of Catania, Italy.
} 
like (Beeton et al. 2006). Images, too, play a vital role in promoting destinations and are essential in place marketing or place selling, substituting previous vague or negative images (Holcomb 1993, Beeton 2015). Aided by the internet, tourists are increasingly visiting destinations that feature in films, or places which they believe correspond to those seen in films (Tooke and Baker 1996). According to Roesch (2009, p. 31), films constitute 'unofficial place-marketing tools', because they create such tourist flows towards destinations that may not have been advertised in traditional contexts. However, Hahm and Wang (2011) indicate that the impact of a film on the featured destination's image and travellers' intentions rely more on specific destination image attributes.

Our mixed methods analytical study focuses on film tourism on the island of Sicily, stimulated by the national and international success of the television series Montalbano, currently in its thirteenth season. Since the series began, there have been steady increments both in tourist flows and in tourist infrastructure in the towns most directly interested, mainly in the province of Ragusa. Official data by Ufficio Statistica-Libero Consorzio Comunale di Ragusa show that, in the last 10 years, the total number of tourist arrivals has increased by $60 \%$, rising from 191,266 in 2010 to 305,729 in 2019 , with a growth of $41 \%$ in the total number of nights, from 731,552 in 2010 to $1,033.712$ in 2019 . These results were mainly driven by international tourists, which reported the strongest increase both in arrivals $(+87 \%)$ and nights $(+46 \%)$. In the same period, the total number of beds saw a growth of $43 \%$, from 15,771 to 22,516 . Although the precise contribution of the Montalbano series to these outcomes is clearly impossible to say, there is no doubt that it has succeeded in bringing visibility to the territories and landscapes of the area (e.g., Lo Piccolo et al. 2017).

The Montalbano series was set by author Andrea Camilleri in the fictional town of Vigata, supposedly identified with the western coastal town of Porto Empedocle, near Agrigento. However, the producers, Palomar and Rai Fiction, took the decision to shoot their version in the more scenographic localities of the Ragusan province, with its Baroque buildings and more appealing scenery. The films are shot in a number of localities - Ragusa Ibla, Modica, Scicli, Noto, Punta Secca and others - which together are proposed as symbolic on-screen equivalents for Camilleri's Vigata. Authenticity, in this context, relates to visits to the 'real' locations shown in the fiction; tourists on a trip to Vigata may go to Scicli's Town Hall, where the rooms used as the inspector's office constitute a sort of museum; they may stay in the Bed and Breakfast at Punta Secca, used as Montalbano's residence in the fiction, and so on. To visit these places is to obtain the thrill of an 'authentic' experience, since tourists are setting foot in the actual places shown in their favourite television programme. However, in terms of criteria for assessing traditional tourist products, it is arguable that their trips are deficient (Pan et al. 2007). Authenticity, for a tourist on a 'Montalbano tour', relates more to the desire to delve into a virtual reality than to the traditional attractions of the places, though these may also play a role in place branding and the design of tourist products (Ponton and Asero 2015).

The issue of authenticity interests not just participants in spontaneous or organised tourist initiatives, but has implications for the region as well. The 
location of the real Vigata has become an issue as these towns, as well as others in Sicily, compete for recognition in the rapidly evolving tourist market. The struggle is leaving linguistic and semiotic traces such as road signs that include references to Vigata, taverns and restaurants bearing the name of Montalbano, and so on. It has thus affected what Landry and Bourhis (1997) term the 'linguistic landscape' of the area.

As Kim and Richardson (2003) say, films may influence perceptions of places, but these effects, it would appear, are not simply limited to the visitors. Rather, it seems that movie tourism may have tangible effects on the places themselves, transforming them so that, to a greater or lesser degree, they resemble the screen versions of themselves. In this context, the popular phenomenon of socalled 'film-tourism' or 'movie-tourism' offer the opportunity for the destination to create its own brand, through branded entertainment strategies and representing images on screen (Horrigan 2009). Our paper probes these issues, asking what the long term effects in terms of authenticity may be, both for towns attempting to rebrand themselves according to a logic of a media dominated market; and for tourists seeking 'authentic' experiences of what are, at best, only virtual forms of reality.

\section{Theoretical Framework}

Images greatly influence tourist destination branding, which is part of the destination marketing process (Morgan et al. 2004, Roesch 2009). According to Kavaratzis and Hatch (2013), the place branding process leads to the establishment of a place identity for a locus, creating new meaning and new symbols. Zenker and Braun (2010) define place brand as an association in peoples' minds of the visual, verbal and behavioural expression of a place, represented through the culture of local stakeholders and of the place in general.

In people's minds, the images for a place are often those that have been created from the narratives of other people, from literature, or because they appeared in a film or on television. Compared to films, the television series has a stronger effect in creating a relation of empathy between viewers and the stories, the characters and places depicted, since they have a longer term impact on viewers (Beeton 2005). As Kim and Wang (2012) noted, the level of media exposure significantly influences both the audience's emotional involvement and on-site screen-tourism experiences.

In researching film tourism, Dann (1977) theorises 'pull' and 'push' factors, which respectively refer to the features of a destination and the intrinsic desires of tourists. Films may be considered as pull factors, since they motivate and catalyse audiences towards a film-related destination. Films are also able to create a 'meaning of place' through the representation of a system of values, shared by members of the same culture (Hall 1997). Such meaning and representation play a specific role in destination marketing. This is understandable, if we consider the reasons that direct tourist flows towards places that have been used as a location (Beeton 2005). As for the push factors of film tourists' motivations, these are 
focused more on internal desires and needs. They can be connected to issues of fantasy, escapism, adventure, search for experiences, or other factors related to the intangible desires of film audiences.

Another general issue related to motivational factors is the desire for authenticity in the tourism experience, which has received considerable attention (Cohen 1988, Brown 1996, MacCannell 1999, McIntosh and Prentice 1999, Thurlow and Jaworski 2011). According to McKercher and du Cros (2002), the term refers to a social construct that depends on the individual's perspective. The desire for authenticity means that tourists are searching for a connection with something that is real and rooted within the destination (Boyle 2004).

However, as Chhabra (2010) argues in the case of heritage tourism, 'authenticity' appears to be an elusive concept since it has multiple connotations. Buchmann et al. (2010), state that different concepts associated to the idea of authenticity overlap, and are often used in accounts of the tourist experience. Therefore, despite its acknowledged importance, authenticity remains a contested term (Xie 2003), since it is applied from a variety of viewpoints, in numerous contexts and situations.

The issue has been a recurrent theme for traditional forms of tourism, which has always faced a paradox: tourists are attracted by promises of 'authentic' experiences with indigenous peoples and unspoilt scenery, but their very presence in those contexts will, in the shorter or longer term, inevitably vitiate the authenticity which they seek. Arguably, such destinations are commodified and, when once they become part of the tourist industry, they risk losing the specific characteristics which put them on the tourist map in the first place. Unspoilt beaches or historical towns lose their charm when the infrastructure of mass tourism arrives on the scene, but there are also more subtle ways in which mass tourism can affect destinations. Images of place, local people, their food and their indigenous, 'authentic' culture represent powerful tourist attractions (see Pan et al. 2007, cited in Francesconi 2012, p. 52, Yeoman et al. 2007). As Thurlow and Jaworski (2011, p. 215) point out, an essential feature of the tourist experience is the encounter with an authentic other, through which tourists are sometimes made to revise their expectations, or re-think their stereotypes. However, it becomes harder to encounter genuine others if large numbers of the host population have begun to work in the tourist industry. As for culture, it appears that certain local populations have begun to improvise so-called 'traditions', solely for the benefit of tourists (Urbanowicz 1989, p. 115). In short, it has been questioned how far it is possible for host populations to retain authentic features of their culture and identity, in the face of the peculiar pressures of the tourist industry (MacCannell 1999, Krippendorf 2013). In film tourism, the authenticity issue emerges with renewed force, since what is involved is already a product that exists at one remove from reality; in media, in other words. Yeoman et al. (2007) use the term 'false reality' in this context.

Wang (1999) offers a classification of the different theoretical approaches to authenticity in tourism studies. He discusses, among other approaches, the role of constructivism, which assumes that authenticity emanates from the influence of social discourses. According to this approach, tourists perceive authenticity as it 
relates to their personal understandings of the term which, therefore, can affect places that were initially perceived as inauthentic and have come to be seen as authentic over the years (Belhassen et al. 2008).

Film-induced tourists are not greatly concerned about traditional notions of authenticity, since they replace them with something personal (Macionis 2004). Destinations for such tourists are increasingly common, and include Northern Ireland (Game of Thrones) or Tunisia and Italy (Star Wars) (Agarwal and Shaw 2018, p. 162). In the case of Montalbano tours, authenticity refers to the sites actually used in the television series and listed above. Whatever alterations the movie industry may have brought about in these locations, the fact that they are visiting the actual places where their favourite films were shot guarantees tourists an experience that they consider truly 'authentic'.

Hence, in the film tourism experience the concept of authenticity can be problematic, since tourist products are created that may modify local cultural assets in accordance with their suitability for movie tourism. For film-induced tourists, products of their fantasy are superimposed on traditional notions of authenticity. We suggest that this commodification process may lead to a loss of authenticity of the local culture, and hence undermine the authenticity of the tourist experience.

\section{Methods}

The first stage in analysing discursive effects of these phenomena was the collection of a corpus of all tourist websites, in Italian and English that make use of the term 'Visit Vigata'. Secondly, these were analysed using a framework that derives from work in multimodality (Kress and Van Leeuwen 1996, Kress 2010). The intention is to probe the realis/irrealis dimension in ideational propositions (Halliday and Matthiessen 2004), in instances of toponymic representation. Scollon and Scollon (2003) define 'realis' phenomena as those that are perceived as real or definite by the person speaking; 'irrealis' is the contrary, concerning things that are imagined, unreal, indefinite, and so on. This linguistic analysis is supported by data and insights from the field of Economics, in the spirit of the type of interdisciplinary textual analysis that features in recent work by, e.g., Weiss and Wodak (2003) and Wodak and Forchtner (2014).

The conceptual notion of irrealis must be distinguished from the grammatical (Kinkade 1998, cited in Bybee 1998, p. 265): technically speaking, a variety of grammatical resources construe irrealis, such as the future tenses, certain forms of modality and negation, the imperative, the conditional and so on. In conceptual terms, however, irrealis may refer to the degree to which speakers' ideas "accord with what they believe to be objective reality" (Chafe 1995, p. 364), and in this sense the role of grammar appears less significant. There is no grammatical clue to alert the reader of Zorba the Greek, for example, that "I first met him in Piraeus" refers to a fictional, rather than an actual, encounter. Rather, it is from the context that this information is transferred; the reader has expectations of the novel genre, which include the notion that the whole text may be irrealis, and does not spend 
much time pondering the issue. However, when a reader of a tourist text comes across the phrase 'Visit Vigata' on a website, accompanying photographs giving details of the place, context knowledge works against correct interpretation. Since everyone knows that such websites exist to promote tours to real places, it is likely that the casual reader will presume that, at the very least, Vigata exists. There is no grammatical clue, here, that suggests that the place is irrealis. If this is true of language, it is even more the case with images, which lack the linguistic means for potentially suggesting the concept of irrealis (e.g., irony, innuendo, intonation, hyperbole, etc.).

We also apply Grice's maxims (Grice 1989) to interpret the sites, extending Grice's traditional focus on linguistic propositions to include the explication of meaning in images. Consider the following example, from our data (Figure 1).

Figure 1. Casa di Montalbano (Montalbano's House) ${ }^{1}$

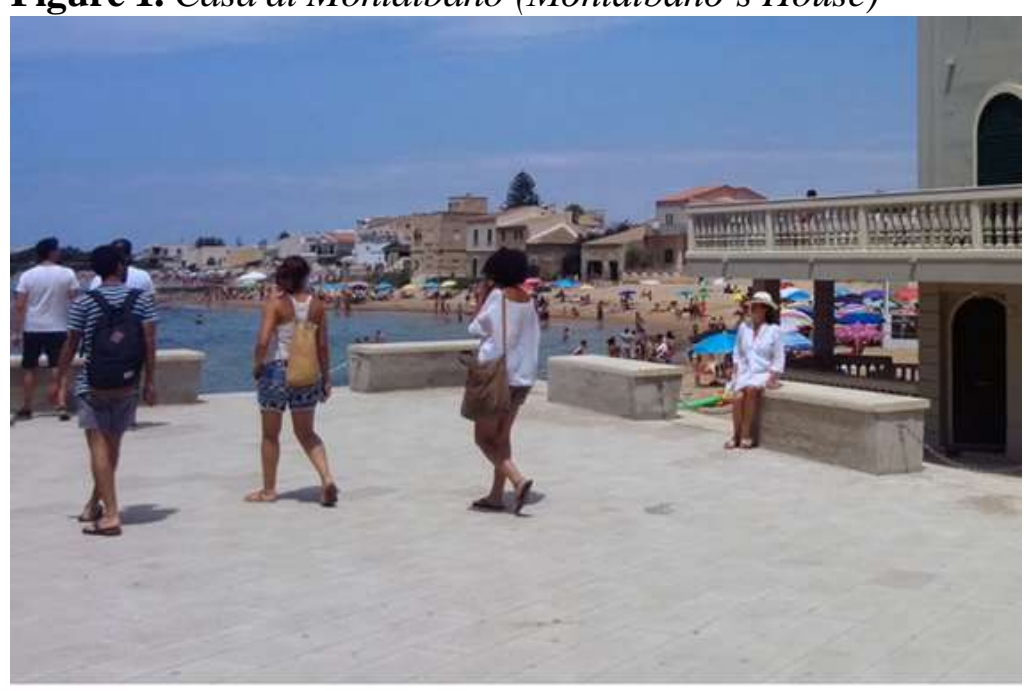

\section{Casa-di-Montalbano Visit-Vigata}

In his essays on visual and verbal representation, Mitchell (1995) uses the term 'imagetext' to capture the essential link between these two semiotic modes and, though it has not caught on yet within multimodality (though see Chan 2011), its usefulness is apparent when attempting to analyse such an image, where the text contributes so much to explication of the meaning. Grice's relational maxim suggests that speech should be both relevant and meaningful (see also Wilson and Sperber 1986, 1998). The text in Figure 1 (above), though not in the spoken mode, is of an interactive kind, and carries the messages: 'this is Montalbano's house' and, via the imperative mood of the second part, 'you should/must visit Vigata'. Text and image, then, combine to permit the inference that the house in the foreground 'is' Montalbano's house (since, if it is not, then Montalbano's house must be one of the more distant ones in the background, and foregrounding is a typical aspect of the photographic genre). By the same reasoning the viewer/reader

${ }^{1}$ Scicli Taxi Service. Retrieved from: https://www.sciclitaxiservice.it/idee-di-viaggio/casa-dimontalbano-visit-vigata/. [Accessed 11 June 2021] 
will conclude that the town in the background 'is' Vigata: tourist brochures do not urge you to visit a place, and meanwhile show you pictures of some other place.

It is possible for the textual mode to explicitly indicate that the events or places described are irrealis, and in our corpus we find such details, e.g.,

Vigata and Montelusa are places that cannot be found on the map

However, it does not appear to be possible for photographs to do the same. As Caldas-Coulthard (2007, p. 288) observes:

A photograph tends to make us believe that what we see is the reality in this sense.

Visual resources tend to be more 'realis' orientated than texts

Therefore, when they see an imagetext such as the above it is probable that potential tourists will understand it as an advertisement for a place that really exists. Only Montalbano enthusiasts will immediately recognise the reference to a fictitious place, though even they may not be entirely sure that there is no such physically existing locus. By these means, our analysis probes the extent to which reality and its opposite (irrealis) are blended in some of these sites, to create a place/no place confusion (Waghorne 2016), which may affect the subjectivities of potential consumers of the products and, as we have suggested above, also the objective contexts of the sites themselves.

\section{Results}

This is not, in any sense, a quantitative study; the images and texts are included to reinforce our main point, which relates to the semi-establishment of Vigata as a 'real' place, and the semiotic means through which this is effected. Some images from our data follow (Figures 2-5). 
Figure 2. Scicli $(\text { Vigata })^{2}$

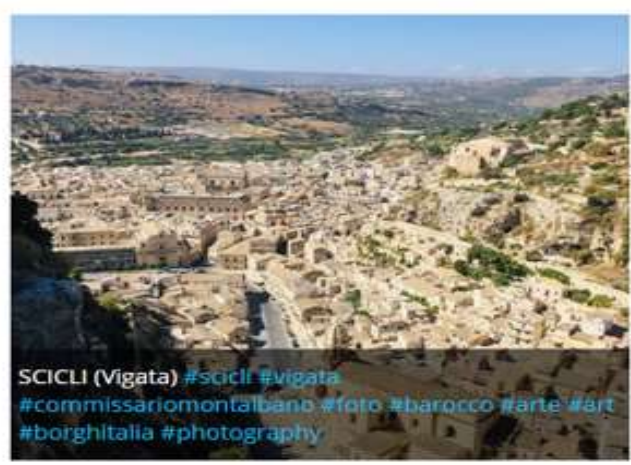

Figure 3. Porto Empedocle (Vigata $)^{3}$

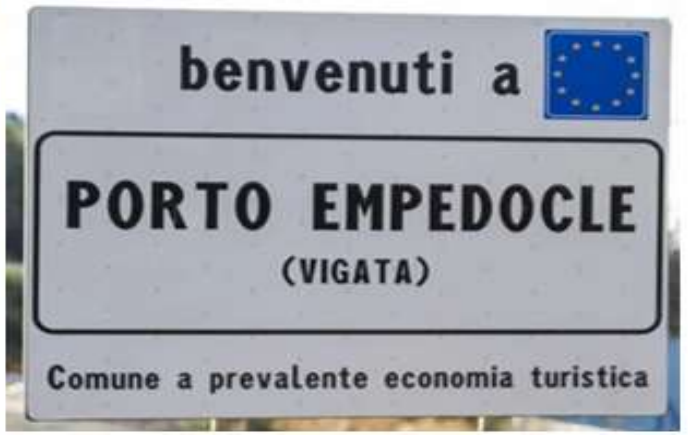

Figure 4. Scicli: la Vigata di Montalbano ${ }^{4}$

Scicli: La Vigata di Montalbano incanta i turisti

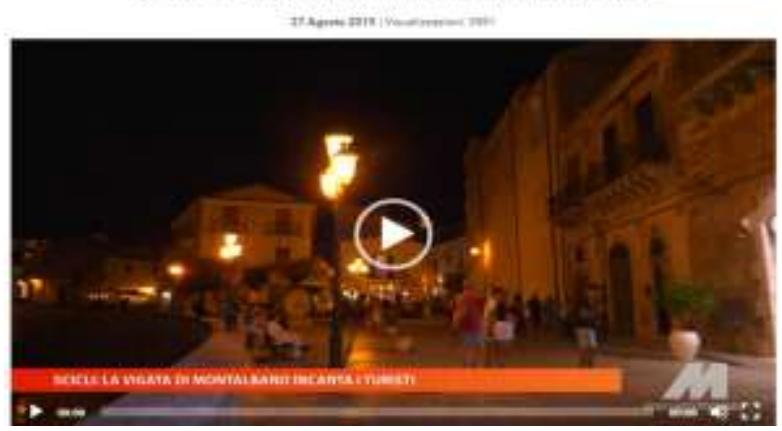

Figure 5. Visit Vigata ${ }^{5}$

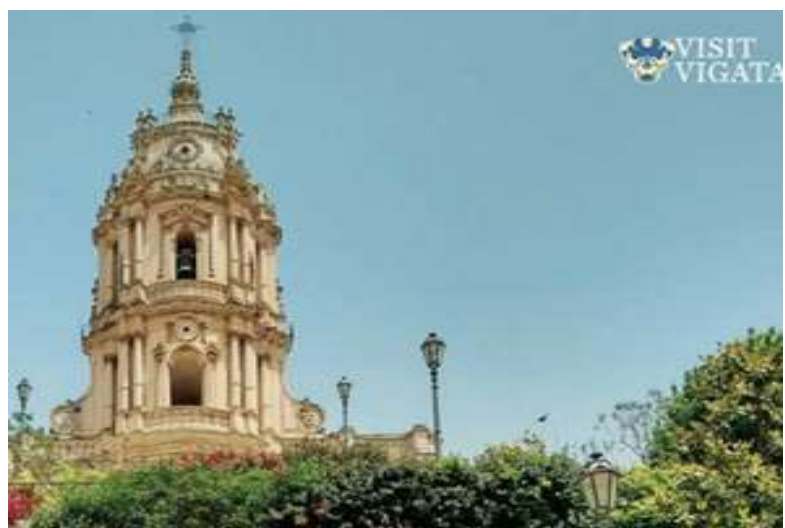

Figure 2 shows a really existing place-Scicli-coupled with a text using the invented name 'Vigata.' As in Mathematics, brackets in this context indicate

${ }^{2}$ Piknow. Retrieved from: https://piknow.net/hashtags/vigata. [Accessed 21 October 2019]

${ }^{3}$ Ragusa Libera. Retrieved from: http://ragusalibera.it/vigata-e-santa-marinella-non-sono-iblascicli-e-punta-secca/. [Accessed 21 October 2019]

${ }^{4}$ Video Mediterraneo. Retrieved from: http://www.videomediterraneo.it/news/attualita/5720scicli-la-vigata-di-montalbano-incanta-i-turisti.html. [Accessed 21 October 2019]

${ }^{5}$ Visit Vigata Facebook page. Retrieved from: https://www.facebook.com/pg/visitvigata/posts/. [Accessed 8 July 2019]. 
equivalence, in other words the message of the textual fragment is: Scicli is Vigata, or Scicli and Vigata are one and the same place. Nunberg (1990: 34) speaks of the "parenthetical of elaboration," of bracket content as providing "an alternative expansion of the preceding noun phrase". The effect here is analogous to that of a phrase like: "The naming of Constantinople (Istanbul)". 6 The text appears before an image of a town; hence, the intended meaning of this imagetext is: here is a picture of Scicli (and Scicli and Vigata are the same place), or simply, here is a picture of Vigata. Since the intended readership (Fairclough 1989, p. 52) of such advertisements consists of Montalbano fans, potential film tourists, it is possible that some may know the background. However, viewers who lack such specialist knowledge are likely to be left with the sense that there are two names given to the same place.

In Figure 3, we find the same punctuation feature, this time on a roadsign at the town of Porto Empedocle. The same pragmatic significance applies, i.e., that Porto Empedocle is Vigata; or, that Vigata is Porto Empedocle. Again, to those who know the Montalbano background, it is possible that they will (correctly) explicate the sign's meaning as: Porto Empedocle is Vigata, in the sense that this is where Camilleri set the stories. This interpretation is helped by the disparity in size of the characters, where the larger font is used for the 'real' town, and the smaller for the fictional. However, those who lack such knowledge will probably conclude simply that the town has two names.

Figure 4 involves a 'colon expansion'; Nunberg (1990, p. 30) speaks of the following content as possibly involving an elaboration or expansion of the preceding element. Here, the phrase, "Montalbano's Vigata enchants the tourists", where the distinction between the factual town of Scicli and the fictional locus, Vigata, will again only be picked up by aficionados of the series. In Figure 5, the slogan 'Visit Vigata' appears over the baroque church of Modica. Once again, one ineluctable meaning of this imagetext is that 'this is a picture of Vigata'.

Vigata, through these linguistic and textual means, is thus visibly linked to diverse really existing localities in contemporary Sicily; Scicli and, in other instances in our data Ragusa Ibla, Cefalù, Punta Secca, Modica and others. The buildings, townscapes and historical monuments of these various places, clearly, have a real-world existence, as well as a significant presence in traditional tourist publicitary material. The combination of irrealis text with images of realis places insinuates to the viewer that what is shown is a picture of a real place; that 'Vigata' really exists, in other words. One textual example illustrates the blending of real and unreal that some of these tourist offers have the potential to enact:

1. Meetup with participants at pre-established time and place, transfer arrangements in minibus and departure for Porto Empedocle.

2. Guided tour of the places that inspired Andrea Camilleri, in Vigata, the little town of 'Inspector Montalbano'.

3. After a brief stop In Villaseta (The snack thief), we'll continue to Vigata, passing by 'Mannara'.

${ }^{6}$ PMOI. Retrieved from: https://english.mojahedin.org/eventsen/203/The-naming-of-Constanti nople-(Istanbul). [Accessed 21 October 2019] 
4. Stop at the port to admire the view of Vigata from the sea. ${ }^{7}$

Here real towns such as Porto Empedocle (1), Villaseta (3) and places like Mannara (3), are juxtaposed with the fictional locus of Vigata. Here, there is no hint that Vigata is any less real than Villaseta, and the text even promises views of Vigata from the sea (4). Inferentially, the picture is as follows:

- ..departure for Porto Empedocle: Porto Empedocle is our destination;

- After a brief stop in Villaseta (the snack thief): Villasetta is a real town, used in the filming of a certain Montalbano episode;

- We'll continue to Vigata: Vigata is a real place, which we will visit;

- ..admire the view of Vigata from the sea: Vigata is a coastal town, and looks good from the sea.

Thus, there is nothing in the grammar that differentiates the explication processes of realis and irrealis sentences, and the overall inference that could be drawn from this text is that Vigata is a real place.

It should be noted that the places that feature as components of the pseudoplace, Vigata, are all, in themselves, to a greater or lesser degree, tourist attractions in the traditional sense, independently of their participation in the Montalbano series. Therefore, the images fulfil many of the requirements for images in traditional tourist magazines, and have a persuasive charge that is independent of references to the Montalbano fiction.

\section{Conclusion}

Movie pictures modify cognitive and affective images of the places they depict, and increase familiarity with them (Kim and Richardson 2003). Media are able to increase the awareness of that place, to disseminate and reinforce the image of a place, to influence the travel preferences of individuals, and hence to create a tourist attraction. In consequence, marketers and destinations are increasingly working with film producers to promote their destinations as film locations while, induced and motivated by film-related elements, tourists visit the film location sites in search of filmic experiences. The implications for tourism destination management are diverse, and include visitor expectations, impact on local communities, tourism planning issues, destination imaging and marketing campaigns.

In film tourism, as said above, there is no pretence at the discovery of any form of exogenous reality, but rather a desire to explore virtual worlds that have been 'experienced' first hand through television or film. As we have discussed elsewhere (Ponton and Asero 2015), there may be a crossover, or blending, between movie tourism and tours of real locations, where visitors who are mainly

${ }^{7}$ SicilytoDo. Retrieved from: https://sicily2do.it/en/tour/alla-scoperta-della-vera-vigata-montal bano-tour/. [Accessed 3 June 2021] 
attracted by a film location also take time out to enjoy the conventional attractions of the locality.

Our study confirms that the recognition of place images, through their depiction in films or television series, affect viewers' perception of destinations portrayed in them, tourist experience and related decision-making. This research also suggests the emergence of new tourism products based on 'Montalbano' and the invented town of 'Vigata'. This is the case with Montalbano's office set (Figure 6), located inside the Municipality building of Scicli, which from July 2018 has been a tourist attraction managed by a local association. In 2018, 14,349 visitors paid to visit the set, increasing to 33,781 in 2019. Even in 2020, when most tourist sites have been closed for many months due to the pandemic crisis, the set recorded 20,694 visitors up to September (Data Source: Municipality of Scicli).

Figure 6. Commissariato of Vigata ${ }^{8}$

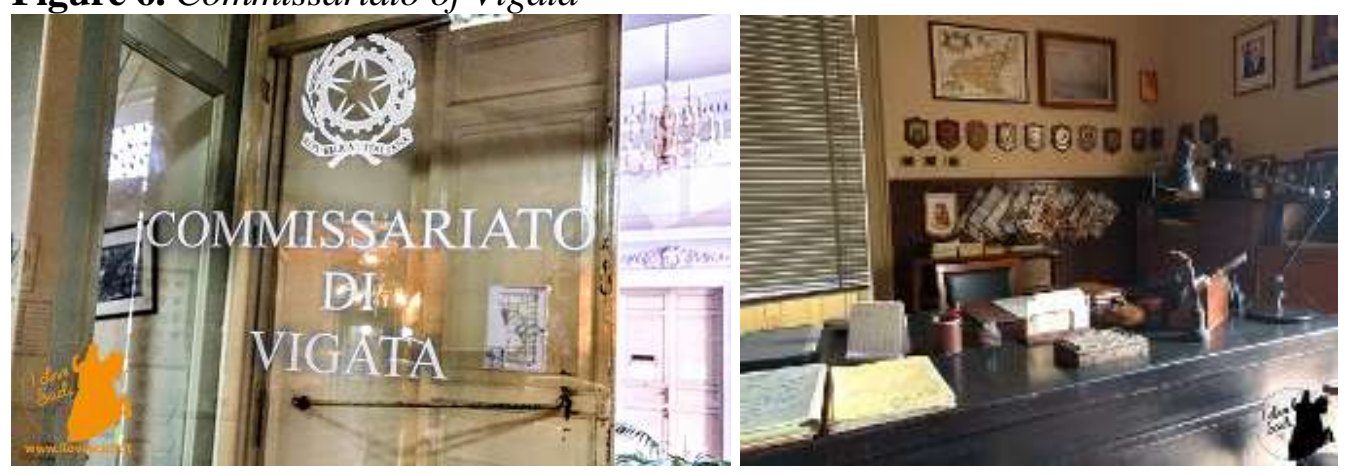

Certain groups of tourists go in search of Vigata, believing that they are staying there, since they recognize places they have seen on screen. From the tourism market perspective, the notion of 'Vigata' has suggested that an imaginary place in Sicily really exists, offering the opportunity to typify different tourism products, which are now located in a 'real' destination without any corresponding 'real' geographical space.

Though from the subjective perspective of the tourist, a pseudo-authentic encounter may be entirely satisfactory, from the point of view of the sites, authenticity is an issue. Economic considerations and possible future pathways of tourism development, we suggest, need to be balanced against more traditional parameters of identity and a sense of place.

This situation is made more complex in a case such as that of the marketing of Vigata, where communes such as Modica and Porto Empedocle may have economic motives for branding themselves as 'the real Vigata', and competing with one another for the title. For the towns engaged in the 'search for Vigata', the development of hybrid identities and pseudo authenticity may be a possible future outcome. In terms of local identity, it is reasonable to ask what may be the longterm implications of an area marketing itself not as a UNESCO site with some of

${ }^{8}$ I love Scicli. Retrieved from: https://www.ilovescicli.it/visitare-il-set-cinematografico-delcommissariato-di-vigata-si-puo/. [Accessed 9 June 2021]. Photos by E. Caschetto. 
the most distinctive baroque churches in the world (a description that would apply to Modica, Scicli and Ragusa, for example), but simply as film sets that happen to have been part of a successful media product.

In conclusion, this study highlights the fact that the setting of movies constitutes an opportunity for a location to be identified as a tourist destination, and suggests that a number of destinations use film tourism initiatives in marketing campaigns to attract tourists and capture visitor awareness. In response to these market trends, and thanks to the 'Montalbano effect', the Southeastern area of Sicily is enjoying an increase in tourist numbers, with benefits on the local and regional economies, though these are not without corresponding issues, some of which have been discussed above.

\section{Financial Support}

Programma di Ricerca di Ateneo UNICT 2020/2022 (PIACERI) linea 2

\section{References}

Agarwal S, Shaw G (2018) Heritage, screen, and literary tourism. Bristol; Blue Ridge Summit: Channel View Publications.

Beeton S (2005) Film-induced tourism. Clevedon: Channel View Publications.

Beeton S (2015) Travel, tourism and the moving image. Bristol: Channel View Publications.

Beeton S, Bowen HE, Santos CA (2006) State of knowledge: mass media and its relationship to perceptions of quality. In G Jennings, N Polovitz Nickerson (eds.), Quality Tourism Experiences, 25-37. Burlington: Elsevier Butterworth-Heinemann.

Belhassen Y, Caton K, Stewart WP (2008) The search for authenticity in the pilgrim experience. Annals of Tourism Research 35(3): 668-689.

Boyle D (2004) Authenticity: brands, fakes, spin and the lust for real life. London: Harper Perennial.

Brown D (1996) Genuine fakes. In T Selwyn (ed.), The Tourist Image: Myths and Myth Making in Tourism, 33-47. Chichester: Wiley.

Bruner EM (2005) Culture on tour: ethnographies of travel. Chicago: University of Chicago Press.

Buchmann A, Moore K, Fisher D (2010) Experiencing film tourism: authenticity \& fellowship. Annals of Tourism Research 37(1): 229-248.

Busby G, Klug J (2001) Movie-induced tourism: the challenge of measurement and other issues. Journal of Vacation Marketing 7(4): 316-332.

Butler RW (1999) Understanding tourism. In EL Jackson, TL Burton (eds.), Leisure Studies: Prospects for the Twenty-First Century, 97-116. State College, PA: Venture Publishing.

Bybee J (1998) Irrealis as a grammatical category. Anthropological Linguistics 40(2): $257-272$.

Caldas-Coulthard CR (2007) Personal web pages and the semiotic construction of academic identities. In T Van Dijk (ed.), Discourse Studies, 275-295. London, Thousand Oaks and New Delhi: SAGE Publications. 
Chafe W (1995) The realis-irrealis distinction in Caddo, the Northern Iroquoian languages, and English. In J Bybee, S Fleischman (eds.), Modality in Grammar and Discourse, 349-365. Amsterdam: John Benjamins.

Chan E (2011) Integrating visual and verbal meaning in multimodal text comprehension: towards a model of intermodal relations. In S Dreyfus, S Hood, M Stenglin (eds.), Semiotic Margins: Meaning in Multimodalities, 144-168. London and New York: Continuum.

Chhabra D (2010) Sustainable marketing of cultural and heritage tourism. Abingdon: Routledge.

Cohen E (1988) Authenticity and commoditization in tourism. Annals of Tourism Research 15(3): 371-386.

Connell J (2012) Film tourism - Evolution, progress and prospects. Tourism Management 33(5): 1007-1029.

Dann GMS (1977) Anomie, ego-enhancement and tourism. Annals of Tourism Research 4(4): 184-194.

Fairclough N (1989) Language and power. New York: Longman.

Francesconi S (2012) Generic integrity and innovation in tourism texts in English. Trento: Tangram.

Grice P (1989) Studies in the way of words. Cambridge, Mass. and London: Harvard University Press.

Hahm J, Wang J (2011) Film-induced tourism as a vehicle for destination marketing: is it worth the efforts?, Journal of Travel \& Tourism Marketing 28(2): 165-179.

Hall S (1997) The work of representation. In S Hall (ed.), Representation: Cultural Representations and Signifying Practices, 13-74. London: SAGE Publications.

Halliday MAK, Matthiessen C (2004) An introduction to functional grammar. 3rd Edition. London: Edward Arnold.

Holcomb B (1993) Revisioning place: de- and re-constructing the image of the industrial city. In G Kearns, C Philo (eds), Selling Places: The City as Cultural Capital, Past and Present, 133-143. Oxford: Pergamon Press.

Horrigan D (2009) Branded content: a new model for driving tourism via film and branding strategies. Tourismos 4(3): 51-65.

Kavaratzis M, Hatch MJ (2013) The dynamics of place brands: an identity-based approach to place branding theory. Marketing Theory 13(1): 69-86.

Kim H, Richardson SL (2003) Motion picture impacts on destination images. Annals of Tourism Research 30(1): 216-237.

Kim S, Wang H (2012) From television to the film set. Korean drama Daejanggeum drives Chinese, Taiwanese, Japanese and Thai audiences to screen-tourism. International Communication Gazette 74(5): 423-442.

Kinkade MD (1998) Is irrealis a grammatical category in Upper Chehalis? Anthropological Linguistics 40(2): 234-244.

Kress G (2010) Multimodality. London and New York: Routledge.

Kress G, Van Leeuwen T (1996) Reading images: the grammar of visual design. London: Routledge.

Krippendorf J (2013) Le vacanze e dopo? Capire l'impatto del tempo libero e dei viaggi. (Holidays and after? Understand the impact of leisure and travel). Milano: Egea.

Landry R, Bourhis RY (1997) Linguistic landscape and ethnolinguistic vitality. Journal of Language and Social Psychology 16(1): 23-49.

Lo Piccolo F, Picone M, Todaro V (2017) South-Eastern Sicily: a counter-factual postmetropolis. In A Balducci, V Fedeli, F Curci (eds.), Post-Metropolitan Territories. Looking for a New Urbanity, 183-204. Abingdon: Routledge. 
MacCannell D (1999) The tourist: a new theory of the leisure class. Berkeley: University of California Press.

Macionis N (2004) Understanding the film-induced tourist. In W Frost, G Croy, S Beeton (eds.), International Tourism and Media Conference Proceedings, 86-97. Melbourne: Tourism Research Unit, Monash University.

McIntosh AJ, Prentice RC (1999) Affirming authenticity: consuming cultural heritage. Annals of Tourism Research 26(3): 589-612.

McKercher B, du Cros H (2002) Cultural tourism: the partnership between tourism and cultural heritage management. Binghamton, N.Y.: Haworth Hospitality Press.

Mitchell WJT (1995) Picture theory: essays on verbal and visual representation. Chicago: University of Chicago Press.

Morgan N, Pritchard A, Pride R (2004) Destination branding: creating the unique destination proposition. Oxford: Butterworth Heinemann.

Nunberg G (1990) The Linguistics of punctuation. Chicago: Chicago University Press.

Pan B, MacLaurin T, Crotts JC (2007) Travel blogs and the implications for destination marketing. Journal of Travel Research 46(1): 35-45.

Ponton DM, Asero V (2015) The Montalbano effect: re-branding Sicily as a tourist destination. On the Horizon 23(4): 342-351.

Roesch S (2009) The experiences of film location tourists. Bristol: Channel View Publications.

Scollon R, Scollon SW (2003) Globalization: the multimodal shaping of public discourse. Retrieved from: http://www. gutenbergdump.net. [Accessed 1 August 2018]

Thurlow C, Jaworski A (2011) Tourism discourse: languages and banal globalization. In L. Wei (ed.), Applied Linguistics Review 2, 285-313. Berlin and New York: De Gruyter Mouton.

Tooke N, Baker M (1996) Seeing is believing: the effect of film on visitor numbers to screened locations. Tourism Management, 17(2), 87-94. DOI: 10.1016/0261-5177 (95)00111-5.

Urbanowicz C (1989) Tourism in Tonga revisited: continued troubled times? In V Smith (ed.), Hosts and Guests: The Anthropology of Tourism, 105-117. Philadelphia: University of Pennsylvania Press.

Waghorne JP (2016) Place/no-place in urban Asian religiosity. Singapore: Springer.

Wang N (1999) Rethinking authenticity in tourism experience. Annals of Tourism Research 26(2): 349-370.

Weiss G, Wodak R (Eds.) (2003) Critical discourse analysis: theory and interdisciplinarity. Basingstoke and New York: Palgrave Macmillan.

Wilson D, Sperber D (1986) Inference and implicature. In C Travis (ed.), Meaning and Interpretation, 45-75. Oxford: Basil Blackwell.

Wilson D, Sperber D (1998) Pragmatics and time. In R Carston, S Uchida (eds.), Relevance Theory: Applications and Implications, 1-22. London and Amsterdam: John Benjamins.

Wodak R, Forchtner B (2014) Embattled Vienna 1683/2010: right-wing populism, collective memory and the fictionalisation of politics. Visual Communication 13(2): 231-55.

Xie PF (2003) The bamboo-beating dance in Hainan, China: authenticity and commodification. Journal of Sustainable Tourism 11(1): 5-16.

Yeoman I, Brass D, McMahon-Beattie U (2007) Current issue in tourism: the authentic tourist. Tourism Management 28(4): 1128-1138.

Zenker S, Braun E (2010) Branding a city: a conceptual approach for place branding and place brand management. In Proceedings of the 39th European Marketing Academy Conference, 1-4 June. Copenhagen, Denmark. 